\title{
Riyadh Development Plans in the Past Fifty Years (1967-2016) ${ }^{*}$
}

\author{
Saleh Al-Hathloul \\ Department of Architecture and Building Science, College of Architecture \& Planning, King Saud University, Riyadh, Saudi Arabia \\ Email: salhathloul@hotmail.com, sh@alum.mit.edu
}

How to cite this paper: Al-Hathloul, S. (2017). Riyadh Development Plans in the Past Fifty Years (1967-2016). Current Urban Studies, 5, 97-120.

https://doi.org/10.4236/cus.2017.51007

Received: January 12, 2017

Accepted: March 28, 2017

Published: March 31, 2017

Copyright $\odot 2017$ by author and Scientific Research Publishing Inc. This work is licensed under the Creative Commons Attribution International License (CC BY 4.0).

http://creativecommons.org/licenses/by/4.0/

\begin{abstract}
Riyadh had grown from a small town of less than half a million inhabitants into a large metropolis of more than 6 million during the past fifty years. The speed and scale of its transformation have had few parallels. This article traces the city urban development and its expansion and growth. It is divided into six stages: the first and second stage set up the base for the city development up to the mid 1960's; the third covers the Doxaidis master plan in late 1960's; the fourth covers the oil boom of mid 1970's and SCET's update of the master plan; the fifth covers ADA efforts to manage the city urban growth in the 1980's and 1990's; the sixth covers the MEDSTAR project, its updates and the initiation of Riyadh Public Transport Network (RPTN) in 2012. These initiatives are briefly analyzed and discussed to understand how the city reached its present physical formation. The paper concludes that Doxiadis plan with its supergrid and the superblock of $2 \times 2 \mathrm{~km}$ provided a rational logical system for the city to expand endlessly. Both SCET and MEDSTAR had followed its approach, method and instruments but at a larger scale. However, two of MEDSTAR proposition, the subcenters and the RPTN project, represent a major departure from the original Doxiadis plan and are expected to change the city's urban order and structure.
\end{abstract}

\section{Keywords}

Riyadh, Urban Development, Doxiadis, MEDSTAR

\section{Introduction}

The city of Riyadh (plural of rawdhah, oasis) was founded on the ruins of several *This article analyzes and documents the urban development of Riyadh, its physical expansion \& planners' effort to manage \& direct this expansion which the author has lived \& witnessed for more than 50 years; as a citizen, a government official responsible for directing spatial development in Saudi Arabia \& as a member of the Arriyadh Development Authority (ADA) between 1984-2004. The author acknowledges ADA help for providing very recent monographs on RPTN project $\&$ the TOD Strategy. 
communities around 1740. Although it was chosen as the capital of the second Saudi state in 1824, it came to prominence only after its independent governor, Abdulaziz Al-Saud, began a campaign to consolidate modern Saudi Arabia in 1902 (Facey, 1992). The speed and scale of Riyadh's transformation since, particularly during the 1970s, have had few parallels. From a walled city of less than 1 square kilometer in 1920, it has grown into a sprawling modern capital of 1500 square kilometers (Figure 1). Its population has increased from an estimated 14,000 in 1902 , to 666,480 in 1974 , to more than 2.8 million in 1992 , more than 4.8 million by 2004, 5.25 million by 2010 (Doxiadis, 1968; GAfS, 1992, 2004, 2010) and more than 6.5 million in 2016 (ADA, 2016).

This article traces the urban \& physical development of Riyadh during the past fifty years. It is divided into six stages which coincide with the physical development of the city. Stage one starts with King Abdulaziz building of Al-Murabba' complex outside the old city. Stage two covers the early 1950's to the late 1960's, in which modern architecture was introduced to the city. Stage three starts with the initiation of the Dioxides master plan in late 1960's. Stage four begins with the oil boom of mid 1970's and the SCET Int. update of the city master plan. Stage five starts with the establishment of Arriayadh Development Authority (ADA) and its role in managing the city's urban growth since the mid 1970's. The final phase comes at the end of the 1990's when ADA undertook the MEDSTAR project and its updates and the initiation of the Riyadh Public

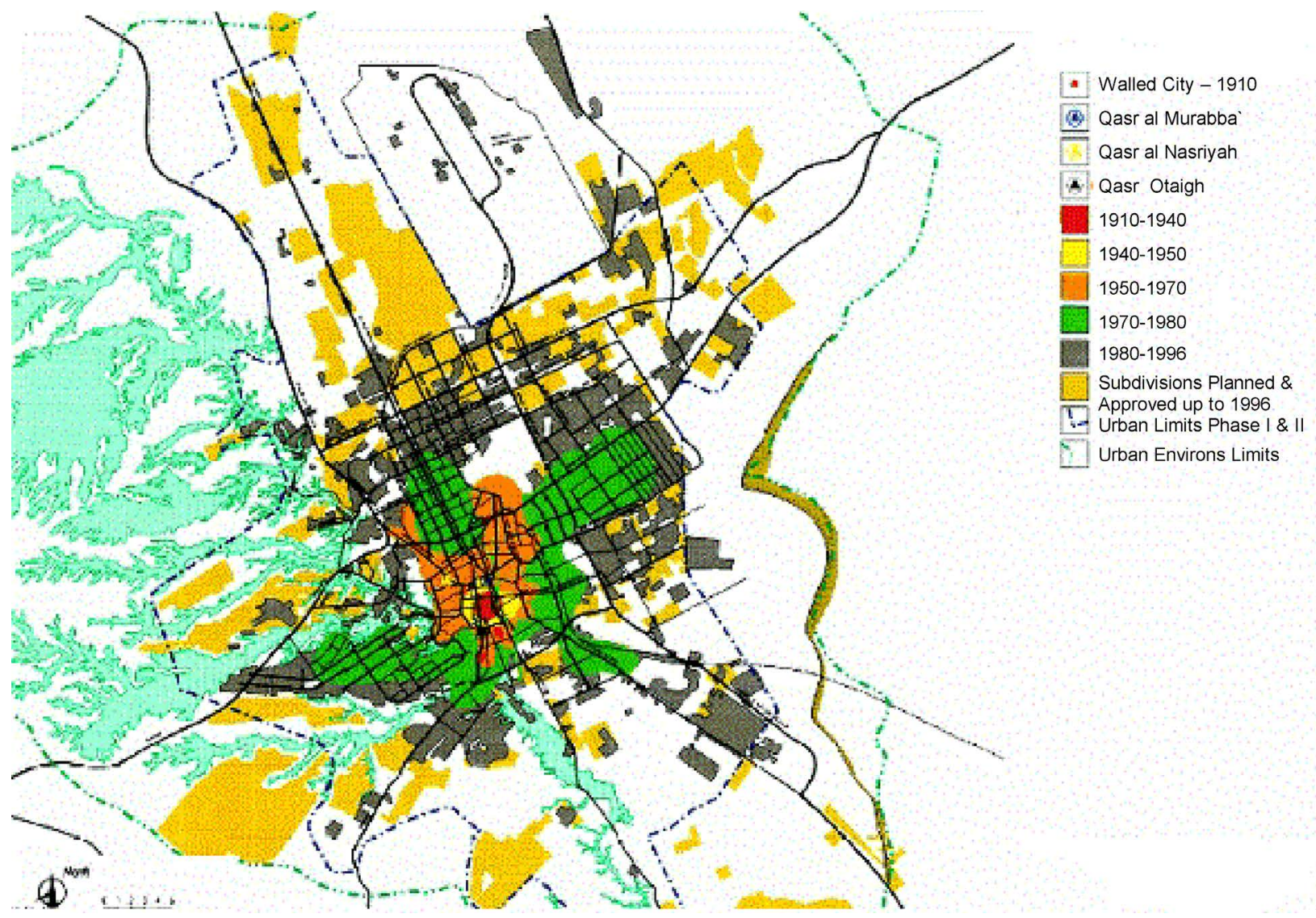

Figure 1. Riyadh phases of urban growth 1900-to-2000. Source: HCDR, 2003: p. 4. 
Transport Network (RPTN) in 2012. These stages and initiatives will be introduced and briefly analyzed in an attempt to understand how the city was physically shaped and how it reached its present context.

\section{Stage One: The Beginning of Riyadh Physical Transformation}

The physical transformation of Riyadh began in the 1930s with King Abdulaziz's decision to build a large palace and an administrative complex two kilometers north of the existing city. Known as al-Murabba', the complex covered an area of approximately 16 hectares (a square of $400 \times 400 \mathrm{~m}$ ) with an average height of two and one-half stories (Philby, 1959: p. 133) (Figure 2).

As an urban design scheme, al-Murabba preserved the general characteristic of the massing of volumes found in Riyadh's traditional urban pattern. This pattern and characteristics can be seen in the continuity of al-Murabba' solid mass, in its covered and somewhat narrow streets, in its squares and courtyards, and in the repetitions of the basic rectangular theme in its general layout and through its detailed components. The departure of al-Murabba from the traditional urban pattern lies mainly in the larger size of its components and the huge scale of the building program.

By building Al-Murabba, King Abd Al-Aziz established a precedent for Riyadh. The affluent now felt that they could build and live outside the city's walls, especially to its north. During the same year of 1938, Crown Prince Saud also built himself a palace adjacent to al-Murabba' site and a spacious mansion was added to serve as the royal guest house. The complex was linked to the town by road. On the road halfway between al-Murabba' and the town, Faisal followed in due course by building a palace for himself, which was to be taken over as an additional guest house once it was completed. In the mid-and late 1940's, several palatial mansions of identifiable pattern sprang up in a new quarter called Al-Futah, on the western side of the road between al-Murabba and the town. These palaces were to be the residences of the King's younger sons (Philby, 1959).

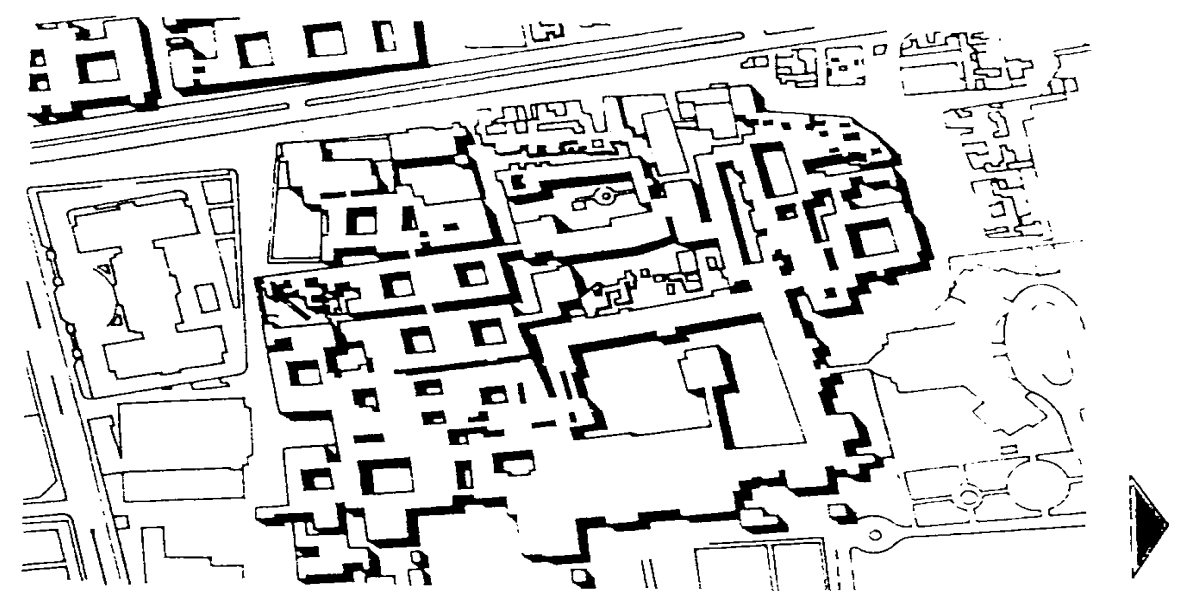

Figure 2. Riyadh Al-Murabba; site plan. Source: Doxiadis, 1968-1972: p. 291. 
This building program affected Riyadh in two ways. First, it stretched the size of the town and set up the direction of its physical growth; it showed that the walls could no longer be a barrier for growth and that north was the preferred direction for development. Secondly, it introduced a new means of transportation, the motor vehicle, which subsequently became the only significant transportation system used in Riyadh. This had a major impact on the old town which had to accommodate the demolition and widening of streets in the 1950's; and, of course, all new developments now had to provide for the automobile, a factor which was not at work during the building of the traditional environment.

Al-Murabba' stands out as an example, which shows that traditional processes and building techniques can continue while at the same time providing for new means of transportation, utilities, and services. Within the laying out of the complex, provisions were made for automobile access, for electricity, and for modern bathroom facilities. However, throughout the new building program, the traditional architecture of Najd was adhered to, and the expanding town continued to preserve the character of the core.

Transformation of the city continued after World War II with construction of an airport and a railway. Railroad tracks were laid between Riyadh and the Gulf city of Dammam, with a station built 4 kilometers east of the old city in 1951. In 1952, a terminal building and a mosque were constructed 7 kilometers north of the city at a landing strip that had been in use since 1946 (Facey, 1992: p. 305-307). In 1951, Crown Prince Saud also built a palace at his farm of Nasiriyyah northwest of the city. These three projects necessitated the city's first major road-building program. Nasiriyyah was linked to Al-Murabba' Palace and the town, with a branch leading to the railway station. Another road was built connecting the airport to the city center (Figure 3). The early 1950s also brought the

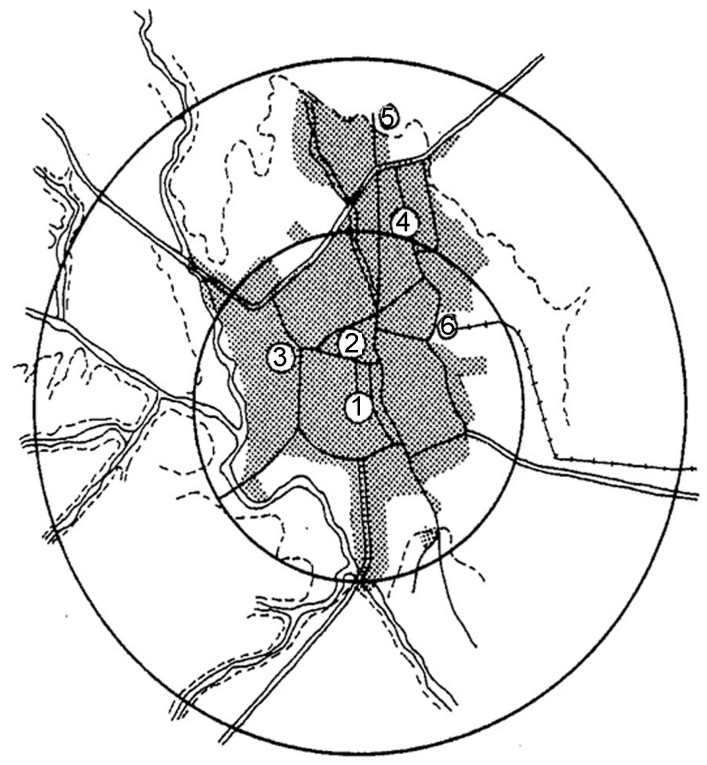

Figure 3. Riyadh, 1970, Sites of the three major building programs and other related areas affecting Riyadh development in the 1950. 1-Old Riyadh, 2-al-Murabba, 3-Nasriyah, 4-al-Malaz, 5-Airport, 6-Railway Station. Source: Al-Hathloul et al., 1975: p. 3. 
end of the old city as an intact physical entity. Its walls were removed, the old governor's palace and main mosque were rebuilt, and streets were widened to provide access for motor vehicles (Facey, 1992).

\section{Stage 2: Asserting Riyadh Position as the Capital City}

After succeeding to the throne in 1953, King Saud made three decisions directly bearing on the future of Riyadh physical development and its expansion. He transferred all government agencies from Mecca and began a program of building new ministries to the west of the airport road; he ordered construction of al-Malaz, a new suburb 4 kilometers northeast of the city, to house transferred government employees; and he expanded and rebuilt his palace at Nasiriyyah (Al-Hathloul, 2003). By 1957, seven ministry buildings, designed by the Egyptian architect Sayid Krayim, were complete. Nasiriyyah had been expanded to cover 250 hectares, employing a grid pattern of boulevards, gardens, and modern structures (Figure 4), and al-Malaz was well on the way toward a goal of providing 750 villas, 180 apartment units, and support facilities. These projects brought new conceptions of space, street patterns, building types, and materials to the city, and together they came to be known as New Riyadh, although al-malaz, in particular, acquired this name.

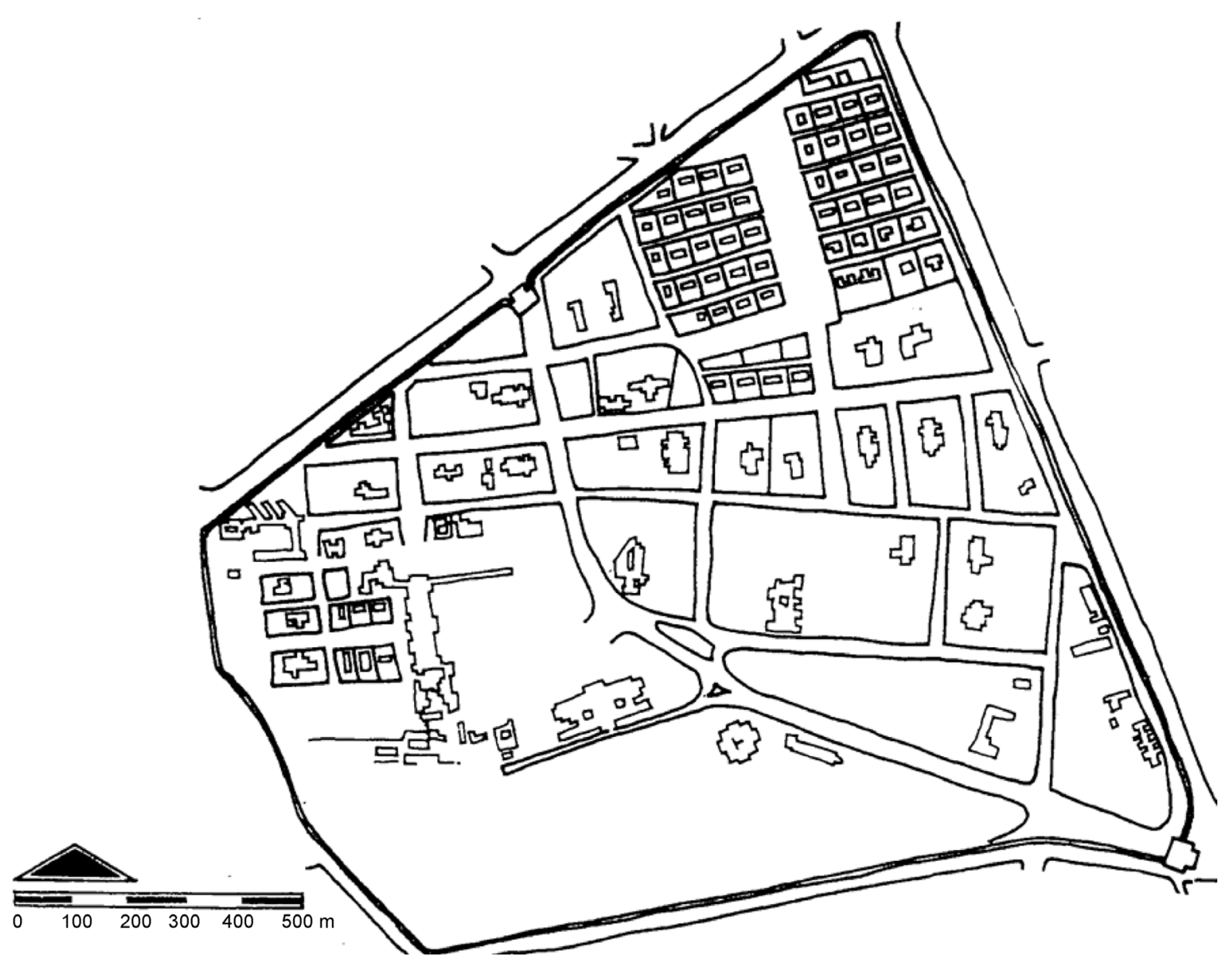

Figure 4. Riyadh - Nasriyah layout plan. Source: town planning office, Riyadh. 
The al-Malaz project consisted of 754 detached dwelling units and 180 apartment units in three apartment buildings. The houses (villas) which were in three sizes, were built and sold to employees on a long-term payment plan; while the apartments were rented on a permanent basis. Al-Malaz included a public garden, a municipal hall and a public library. It also housed the buildings, originally planned as schools, for the newly founded University in 1957. In addition, it also had a race course, a football field, and a public zoo; supporting facilities such as schools, markets, and clinics were planned, although they were built by different agencies (Figure 5).

The physical pattern of al-Malaz follows a gridiron plan with a hierarchy of streets, rectangular blocks, and large lots which in most cases take a square shape. Thoroughfares are $30 \mathrm{~m}$. in width, main streets $20 \mathrm{~m}$, and $15 \mathrm{~m}$. A $60 \mathrm{~m}$ boulevard divides the project into two parts. Most blocks there are $100 \times 50 \mathrm{~m}$. The typical lot size is $25 \times 25 \mathrm{~m}$, but with some blocks there are a variety of widths, such as $25 \mathrm{~m} ., 37.5 \mathrm{~m}$., and $50 \mathrm{~m}$. The depth of $25 \mathrm{~m}$, however, remains constant in almost all the blocks.

Comparing this newly introduced pattern with the traditional pattern of al-Dirah, Riyadh's oldest neighborhood, one can see that new values in the conception of space have been introduced: a very low density, one-fifth that of the traditional; a large area assigned to streets, three times that of the traditional; and only half of the area reserved for private lots, as compared to more than seventy-five percent in the traditional. In addition no provision is made for semiprivate space, an essential element in traditional environments (Al-Hathloul et al., 1975).

Al-Malaz's impact on the size of Riyadh can be easily seen. It covers an area of about 500 hectares. It is a city by itself as the invention of the name New Riyadh implied. But what was not seen at the time of its initiation was the impact it should later have on the pattern of physical development in Riyadh as well as all over the country. Al-Malaz introduced new patterns and new types. The grid as a street pattern and the villa as the new house type both became models for the new physical development that took place since the 1970's in every city and town in Saudi Arabia.

The question does arise as to why al-Malaz, rather than al-Murabba or Nasiriyyah, became the model to be reproduced in future developments in Riyadh and elsewhere. Three main reasons suggest themselves. The first is that it was a housing project, sponsored by the government for its employees. It was therefore, an authoritative statement by the government on how a modern neighbourhood should be planned. As such, it reflected the government's vision and point of view on how the new and vastly growing Riyadh should be built. And, of course, it was taken for granted that what are good and suitable for Riyadh must be good for the country's other cities as well. The second reason is that al-Malaz was seen as a symbol of modernity, in sharp contrast to tradition. It was the New as opposed to the Old Riyadh. Since, unfortunately, it was the only project to use new materials and techniques, no other modern alternative was 

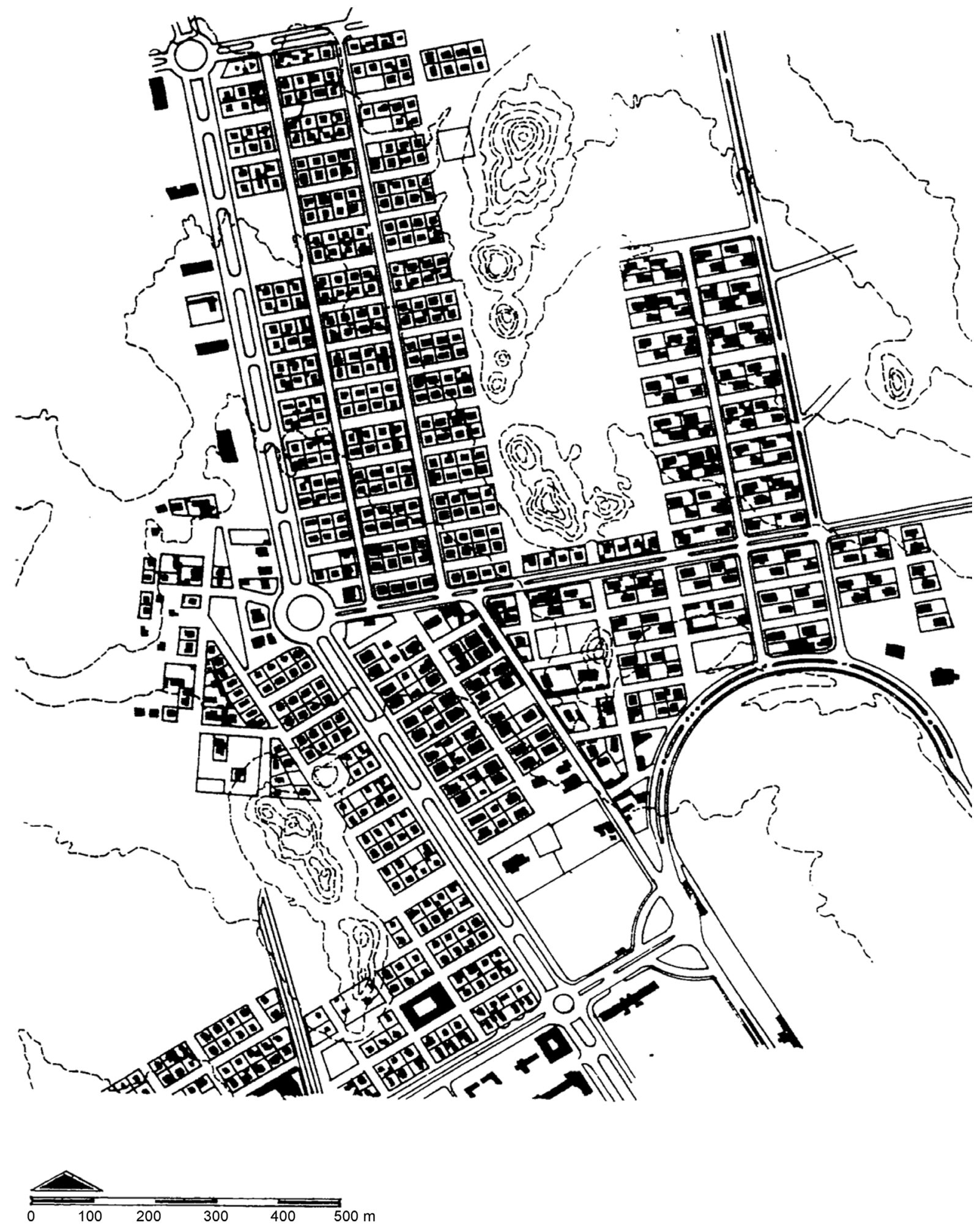

Figure 5. Riyadh - Al-Malaz layout plan. Source: Al-Hathloul et al., 1975: p. 39.

available for the inhabitants of Riyadh to see, admire and then imitate. The third reason is that, in contrast to the royal residences of al-Murabba' and Nasiriyyah, al-Malaz was built for government employees who were part of the public. As leading opinion makers in establishing the taste and style of life in Saudi Arabia 
in the 1950's and 1960's government employees were highly regarded by other segments of the society, and their lifestyle was greatly coveted. When they moved to al-Malaz with its villas and newly planted trees, almost everyone dreamed of settling into a new and similarly planned neighbourhood. Rising expectations continued to mount and land speculators made good use of them.

As Riyadh continued growing through the 1950's and into the early 1960's, other neighborhoods were built, and apartment buildings appeared along al-Thumairi, al-Wazir, and al-Khazzan streets (Al-Hathloul, 1996).

\section{Stage 3: The Dioxides Master Plan}

A new phase of Riyadh's urban growth arrived in the late 1960's. Then, the government of Saudi Arabia felt the need to control and direct growth in urban areas. Riyadh, the capital, was the fastest growing city in the country and the most important from the government's point of view. It was therefore, the first to attract the attention of authorities, and in 1968 the task of planning the capital was assigned to Doxiadis Associates. A contract was signed between the Ministry of the Interior for Municipalities and Doxiadis Associates, Consultants on Development and Ekistics of Athens, Greece. The contract provided for the formulation of a Master Plan and a Program that would guide the development of the city of Riyadh up to the year 2000 (Doxiadis, 1968).

The final Master Plan for Riyadh was submitted in 1971 and was approved and sanctioned by the Council of Ministers in 1973 (HCE, 1973). Here we will introduce a brief analysis of the plan, its goals, provisions for land use, circulation, and overall structures (Figure 6).

The goals and policies touch on a variety of subjects such as the form and shape of expansion, community buildings and open spaces, communication links, arrangement of functions, housing, transportation, public utilities, and industry. Regarding the city's future growth, the plan states:

In order that the city of Riyadh will be able to grow within the broader area that surrounds it, it should take a shape or form that is adapted to dynamic growth. Such a pattern should be open-ended with a central spine allowing the city to grow as its population increases. The spinal cord of such a plane should be a zone of central commercial business and administrative functions designed so that it can expand at the same time as the residential and other functions it will serve are growing...

Human settlements (should be seen) as living organisms that are supposed to serve the needs of their inhabitants from every point of view. This leads to two basic principles. The first dictates the adoption in general lines of a linear growth pattern for the city...

The second regards the structuring of communities of the city... The organization of the characteristic elements of city life should be made on the basis of a unit that is richer in variety and content than the present day building block...

A balanced transportation network with a hierarchy of streets that are well-tied in with a balanced distribution of functions in the city should be one of 


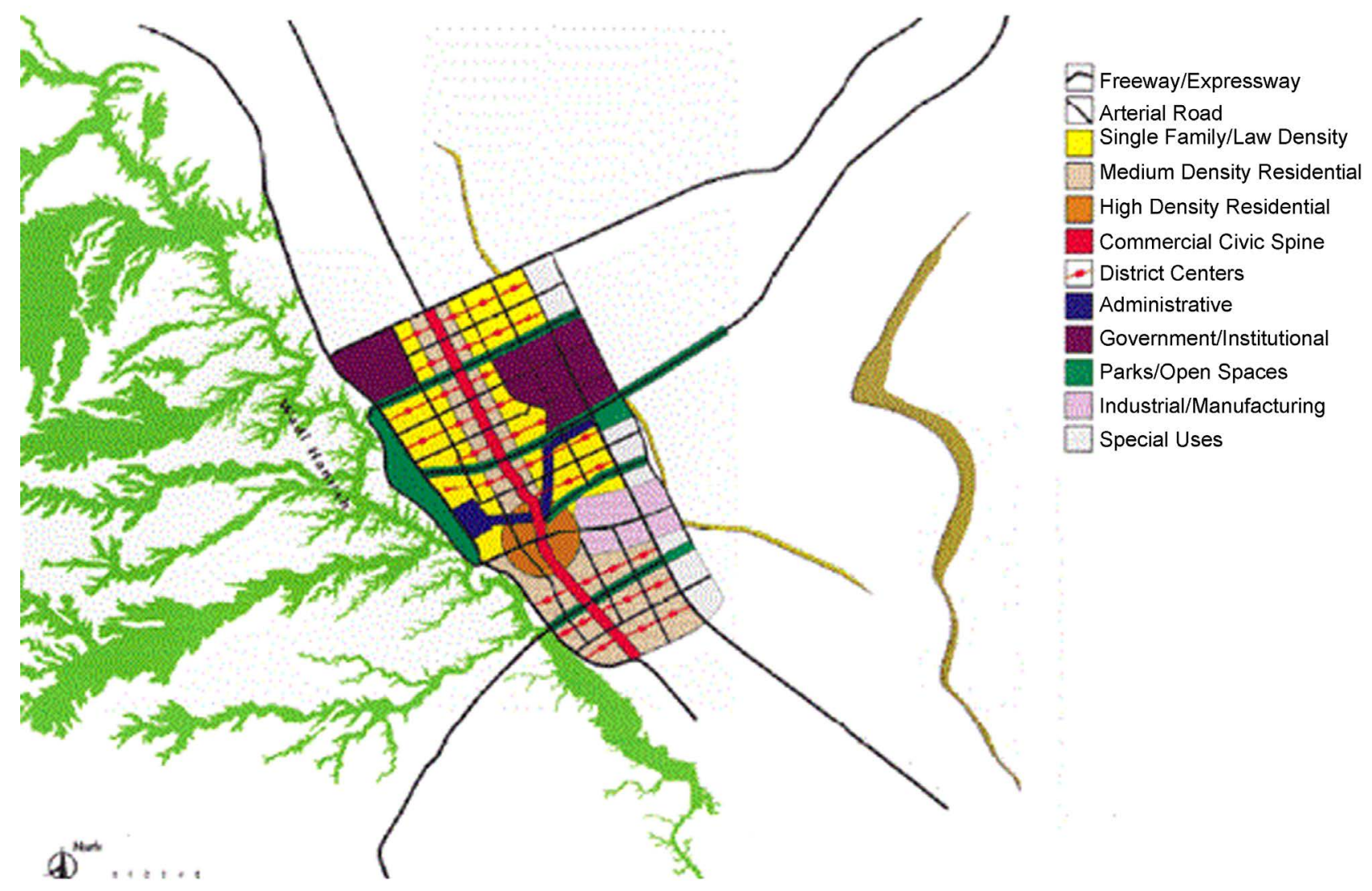

Figure 6. Riyadh - Dioxides master plan 1972. Source: HCDR, 2003: p. 5.

the main goals for the normal growth of Riyadh..." (Doxiads, 1971: p. 100-106).

Concerning structure, the plan is composed of a supergrid which runs in a north-south and east-west direction. In this grid, the city is cut into six large divisions, each composed of eight to twelve localities of $2 \times 2 \mathrm{~km}$. This locality, a square unit, represents the basic component of the grid and, according to the plan, is determined to be the best size for a neighborhood. The plan refers this square unit to the idea of Murabba' which is a basic traditional element in the city (Doxiadis, 1971).

With respect to land use, the physical plan for the development of Riyadh is composed of a major commercial and civic spine which extends to the north and south of the existing business district; and an administrative area which is situated perpendicular to the civic and commercial spine; and residential districts which extend from both sides of the spine. A strip of industrial and special-use areas runs parallel to the spine forming a man-made boundary on the east. On the other side, the west, the steep cliff formations of Wadi Hanifah form a natural boundary for the city. These boundaries direct the development of the residential areas into a line parallel with the city spine (Doxiadis, 1971).

In terms of circulation, the plan of Riyadh shows that private automobile will continue to be the only mode of transportation. The circulation pattern is planned to have the following hierarchy: four major freeways, connecting the city with the country freeway system, and serving high-speed, long-distance and 
through-trip traffic on a national, regional and urban scale; expressways, intended to serve large volumes of high-speed, long-distance urban trips with partial control of access; arterial roads, designed to accommodate a large volume of medium and long-distance urban trips, and whose role is to facilitate through movement and direct service to the adjacent communities; collector roads, which are streets intended for short urban trips and direct connection of communities with the city's main network; and local roads, intended exclusively for access to abutting properties and for very short trips (Doxiadis, 1971).

The Master plan of Riyadh confirms and enhances the trends of the 1950's and 1960's. By introducing the supergrid as a plan for the city and using the grid pattern in its proposals for the action area studies, the plan institutionalizes the grid as the most desired pattern to be followed in the planning of Riyadh. And by continuing and preserving the trends of large lot sizes that were introduced in al-Malaz and setback requirements that were developed from there, the plan also institutionalizes the villa as the most desirable dwelling type.

Most of the criticism for the plan is based on the fact that it did not adequately anticipate the size of urban growth which took place in Riyadh in the mid and late 1970's. This growth made the plan obsolete, but it was beyond the capability of the consultant to predict the economic oil boom of the 1970's and its adverse effects on the city's physical growth. However, little has been mentioned about the contradictions within the plan. Regarding density the plan calls for a compact city, but sets the overall density of no more than $140 \mathrm{p} / \mathrm{h}$. This is being ensured through the minimum lot size, the bulk and height regulations and the standard minimum street width (Al-Hathloul, 1996). Regarding scale and character of the city, the plan states:

The task is not simply the development of a well-structured Master Plan that will function well, but also of a Master Plan expressing the characteristics of Riyadh, Saudi Arabia...

...If one excludes some residential developments indifferently planned on Western prototypes, the rest of the city has a cohesion and style, which is given by the rectangular formation of its blocks, by the use of certain basic dimensions within the city and by the use and repetition of traditional patterns and aesthetic elements.

...(These) physical dimensions, in turn, reflect human dimensions, human contacts and human life. These values are the values that must be preserved in the planning and design of the future city (Doxiadis, 1971: p. 73).

Again the proposed measures and regulation introduced by the plan seem to have been designed to ensure a totally different pattern of development. By mandating a large minimum lot size and setback requirements all over the city new development (HCE, 1973: p. 132), the plan actually ensures the departure of new Riyadh from its traditional past, both in scale and in character.

In spite of the criticism levied on the plan, one must acknowledge its flexibility and ability to endure and accommodate the expansion of Riyadh during the past fifty years. Doxiadis saw the central problem with most existing settlements 
such as Riyadh is that they only allowed for a limited degree of urban growth due to the inherent restrictions of their spatial structure. He did not believe in satellite and argues that satellite as a detached settlement form does not integrate into the expanding and dynamic settlement. Thus, he tended towards the linear concept of city form and developed his model of Dynapolis. However he argued that Dynapolis is totally different from the linear city. He reasons that Dynapolis has no limits, it is non static, it does not necessarily has the same dimension and formation at every point along the axis, and it can grow only in one direction. He also believes that ideal physical planning solutions must respond to the needs of the future not just the present (Khan, 2010; Middleton, 2009). Thus he opted towards the development of the grid as a spatial structure for the city of Riyadh.

Doxiadis intention when proposing the Dynapolis was to develop a dynamic urban settlement that would expand in one direction, and preserve circulation patterns, urban centers and residential community districts. This spatial concept established a rational spatial structure built on a hierarchical system of communities, transportation and infrastructure. This conceptual model established a rational strategy and methodology for the organization of Riyadh urban territory to structure and facilitate the dynamic process of expansion and charge (Middleton, 2009). Thus Doxiadis established a comprehensive vision of urban development, which enabled an unhindered growth of the city of Riyadh.

\section{Stage 4, The Oil Boom of the 1970's and the SCET Int. Plan}

Great changes arrived in Riyadh following the oil boom of the early 1970's. The government expenditure increased sharply leading to a dynamic population growth and a high rate of urban development exceeding the city boundaries defined by the Doxiadis plan. Building permits issued by the Municipality at that time reached more than 12,000 permit annually, not including large scale government projects such as the airport, universities, medical centers, etc., leading some critics to describe the city as the biggest construction site in human history (Figure 7).

By mid 1970's, it became clear that the forecasts and predictions, and hence some of the proposals, of the Doxiadis plan had become obsolete. This revealed the need for ongoing adjustments and phasing to correspond to the city's rapid growth. Thus new studies based on new facts and a different context had to be prepared.

In 1976 the Deputy Ministry for Town Planning, Ministry of Municipal and Rural Affairs assigned the task to SCET International/SEDES of Paris. SCET was required to revise and update the Doxiadis Master plan (SCET, 1979). SCET's

\begin{tabular}{|c|c|c|c|c|}
\hline Year & No. of Permits & & Year & No. of Permits \\
\hline 1975 & 8284 & & 1978 & 11,231 \\
\hline 1976 & 9813 & & 1979 & 11,450 \\
\hline 1977 & 11,206 & & 1980 & 12,154 \\
\hline
\end{tabular}

Figure 7. Building permits issued by the municipality between 1975-1980. Source: building permits department, municipality of Riyadh. 
expertise was in the development of urban and national infrastructure. Thus they undertook a holistic evaluation of services to support the expanding city and developed a revised expansion and phasing plan (Al Mogren, 2016).

The supergrid with the $2 \times 2 \mathrm{~km}$. planning network was maintained and extended in all directions where development have taken place. The city growth was affected by the big projects which were located outside the original Doxiadis plan which the new plan tried to integrate into the city fabric (Al-Hathloul, 1996) (Figure 8). The need for a ring road become obvious early on and was a key feature of the SCET update of the Doxiadis Master Plane in 1978. The SCET Plan initiated and defined the path for the ring road, developed the action plans for the implementation of king Fahad Road, Which is a major element defining the Doxiadis spine, and accommodated new projects and connected new areas outside the Doxiadis plan; i.e. the new airport on the northeast, the diplomatic quarter on the west, the National Gauds Campus and the new neighborhoods on the east, and the new subdivision for low income groups located in the southwest of the city across Wadi Hanifah (Al Mogren, 2016; Middleton, 2009). The idea of locating this subdivision across Wadi Hanifa was discussed with Doxiadis in 1969, but excluded on the basis that the area is unsuitable for residential development due to its difficult topography. This new development required technical integration with the existing infrastructure and with the Doxiadis master plan organization (Middleton, 2009).

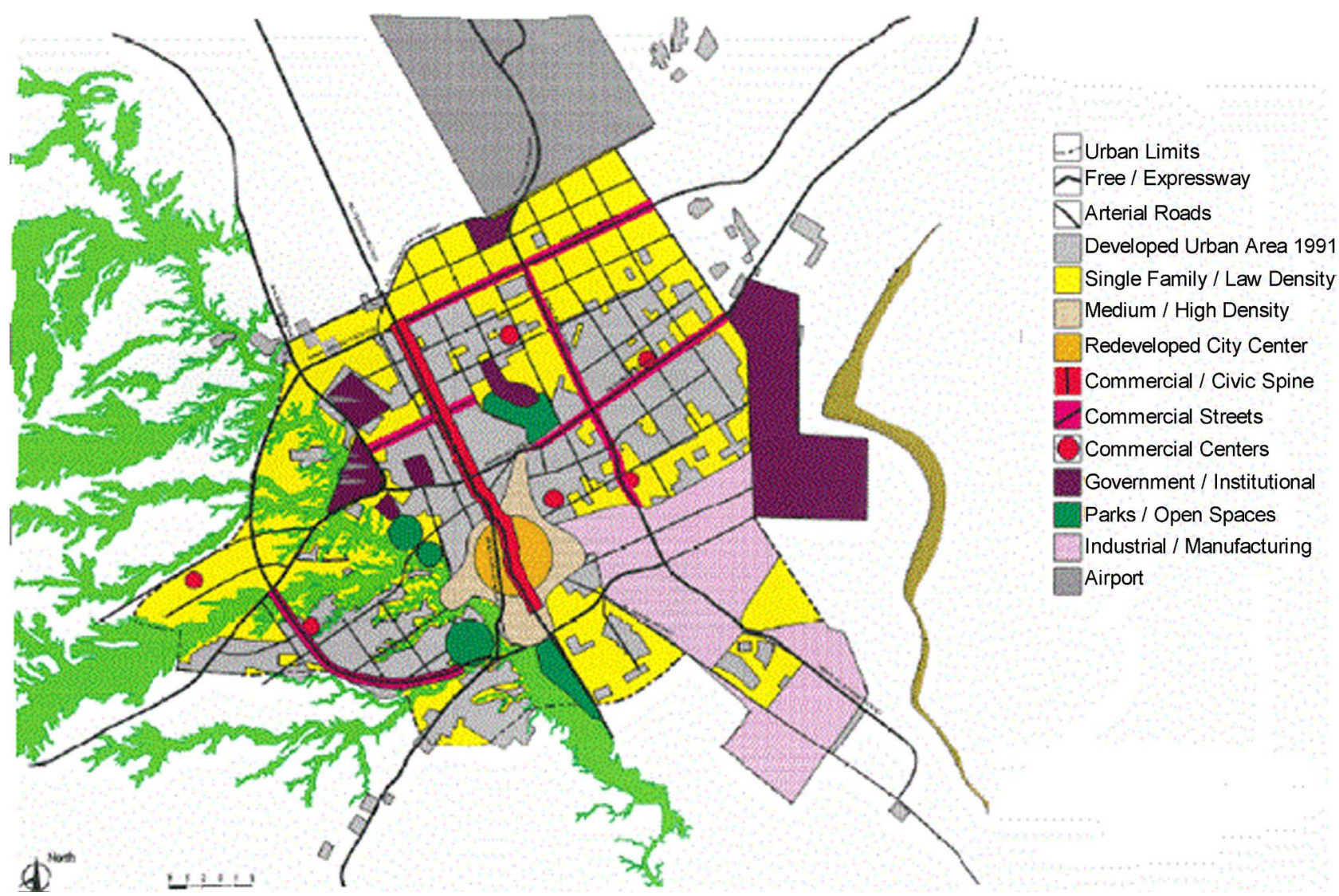

Figure 8. Riyadh: the updated master plan by SCET international/SEDES, 1982. Source: HCDR, 2003: p. 6. 
The SCET plan made a good use of the inherent flexible nature of the super grid provided by the Doxiadis plan. It retained the same guiding principles of the Doxiadis Plan, but expanded the scope to deal with the unforeseen growth. Thus it was an expanded version not a replacement of the Doxiadis plan. However, the SCET plan had a profound impact on Riyadh:

1) The proposed ring road came to redefine the organization of the city. It allowed the spread of mega commercial development rather than limiting it to the central axial spine as Doxiadis proposed and opened new areas for concentrate industrial development.

2) By allowing the low income subdivision, it set a precedent for development on the western side of Wadi Hanifa.

3) By encompassing all projects and development outside the original Doxiadis plan into the master plan it proved the flexibility of the Doxiadis super grid and showed that this grid could be endlessly expanded.

4) The plan also defies the Doxiadis proposal of locating a main commercial center in each Block of the super grid to meet the community needs and free the main grid roads from heavy activities. Rather, it allowed all main streets including roads defining the superblock to have commercial uses. This Action had a very great impact on life and activates within the city and its neighborhoods.

\section{Stage 5, Managing Urban Growth}

To implement the Doxiadis plan, the government created a technical committee chaired by the Riyadh governor that would later form the nucleus for the Arriyadh Development Authority (ADA). Since its inception in 1974, this government authority has guided Riyadh's development and carried out large-scale building and renovation projects in the city center, the al-Murabba' district, and elsewhere in the metropolitan area (Othman, 1995).

One of its most important Projects has been development of the Diplomatic Quarter (DQ), a new town in town. A 586-hectare site was allocated for this project 8 kilometers northwest of the city center after the Saudi government decided to transfer foreign diplomatic missions from Jeddah to Riyadh in 1975 (Al-Alsheikh et al., 1990). The master plan for the DQ was by Speerplan, Regional Und Stadtlplaner (GMBH; its central area urban design was by Beeah of Riyadh, and the layout of its residential districts was by Farahat Tashkandi (Al-Hathloul, 2003) (Figure 9).

\section{Urban Growth Boundaries}

The delineation of Urban Growth Boundaries (UGB) is a national program undertaken between 1986-1989 for 100 cities within Saudi Arabia. A freeze on new land subdivision in all cities was imposed in 1986 by the Council of Ministers. The council directed MOMRA to prepare UGB for all cities and present it for approval of the Council within two years. The program has three main goals:

1) Control urban sprawl by encouraging infill development,

2) Reduce the cost for provision of infrastructure for new development through better coordination, 


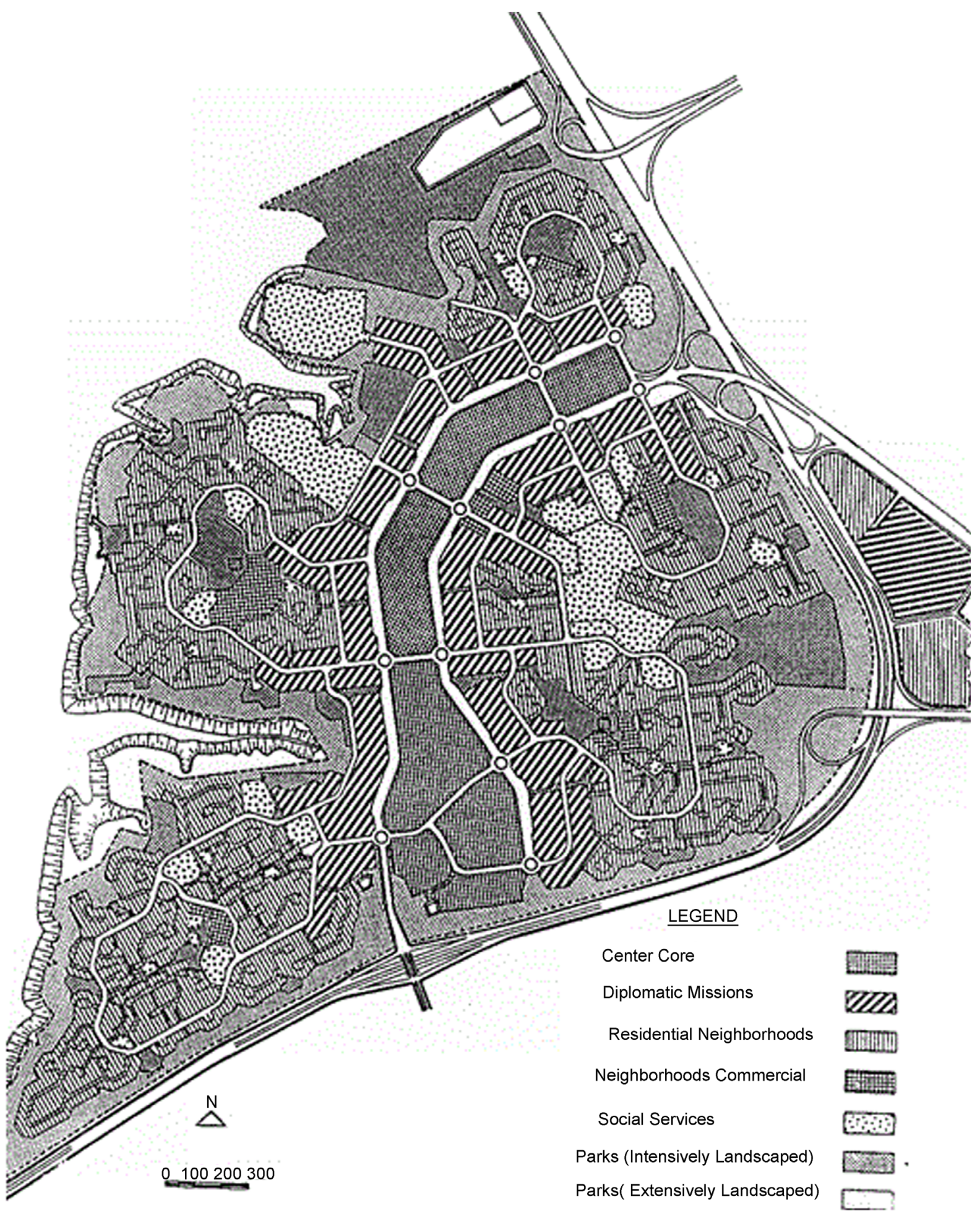

Figure 9. Riyadh: the diplomatic quarter layout. Source: adapted from: Al-Alsheikh et al., 1990: p. 80.

3) Ensure the maintenance of natural environment around cities through preservation measures (Al-Hathloul \& Mughol, 2004).

During the 2nd half of 1980's, Riyadh was expanding out of proportions. Doxiads plan determined its area at 30,400 hectare with 1.2 million inhabitants by the year 2000 . However by 1987 it has an area of 45,197 ha. and a population 
of 1,389,000 inhabitants (Al Mogren, 2016). The SECT plan was more of an organizational tool than a controlling force, it did not aim to curb expansion or set boundaries for Riyadh physical growth, rather it merely organized its expansion, and specified parameters for how this physical expansion should proceed.

The ADA went along with the UGB program, and carried out the task of delineating UGB for Riyadh (Figure 10). This was composed of three phases. First phase, encompassed that is open area for development of 13,710 hectare up to the year 1995. Second phase encompassed an area of 51,680 up to the year 2005 (DMTP, 1989). The outer or third phase was designated as a protection zone for urban development. The underlying factor was to provide enough land to cater to the needs of the present and projected population needs for the two phases. However, as there existed plenty of subdivided land In Riyadh, the boundary delineation was not based on future requirement of land alone but the judicious use of subdivided land become a crucial factor. Thus the end result was a liberal delineation of the boundaries for the city (Al-Hathloul \& Mughol, 2004).

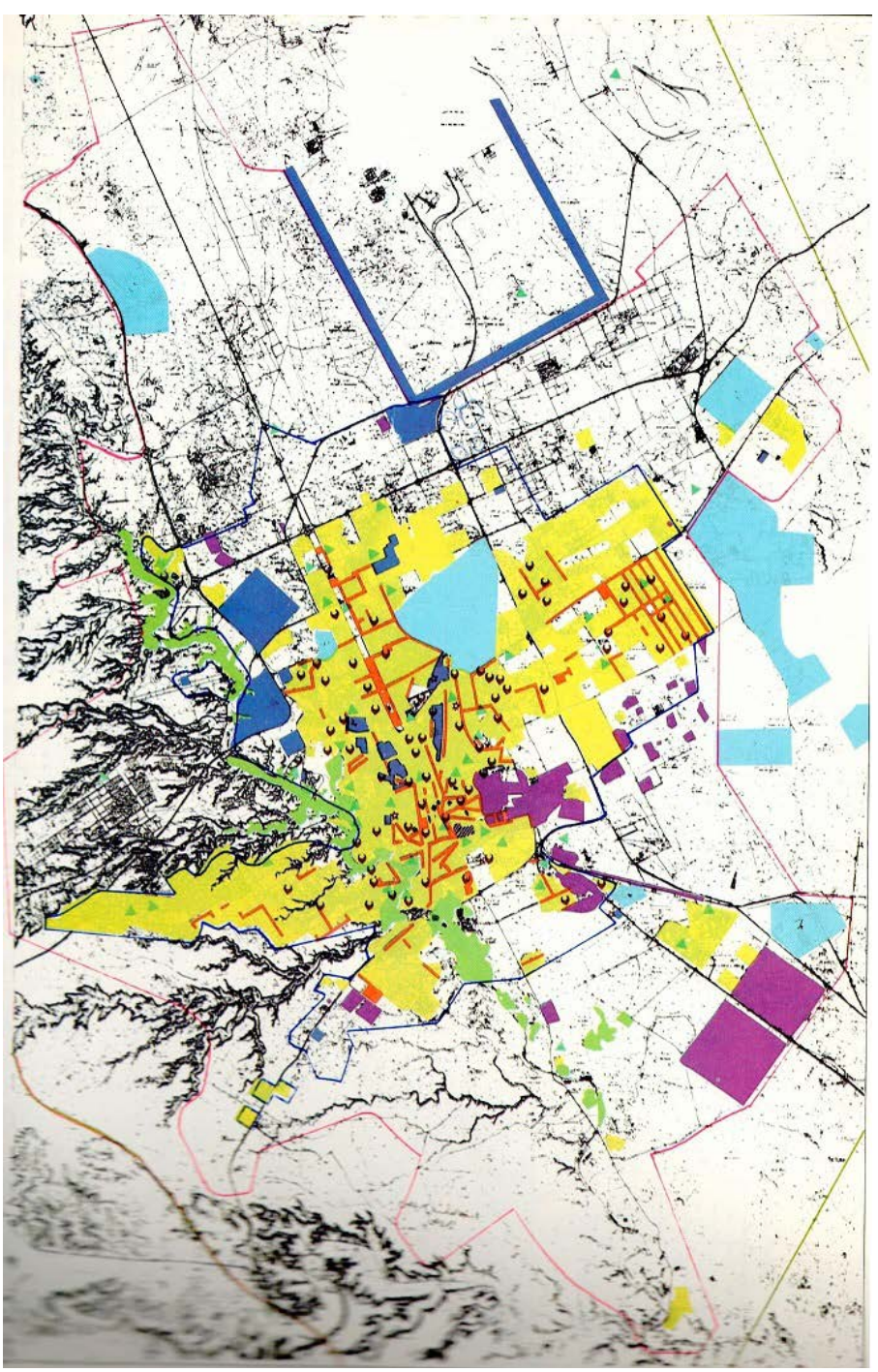

Figure 10. Riyadh urban growth boundaries: 1995 \& 2005. Source: DMTP, 1989: p. 2. 
Provision of utilities and services within the 1st phase was the responsibility of Municipality, while in the 2 nd phase this responsibility was diverted to developers. Thus no subdivision in the 2 nd phase can be approved without the provision of utilities by the developer. As a result of the freeze and phasing process between 1986-1993 an average of 1150 hectare of vacant serviced land was brought to full use annually. Thus the strong role of the government in the provision of free infrastructure was used as an effective tool in shaping the growth patterns (Al-Hathloul \& Mughol, 2004). However, some developers benefitted from the permission to subdivide their land within the 2 nd phase before end of the 1 st phase and they provided infrastructure and utility. This did defy, to some extent, the objective of the UGB program in Riyadh but it did not affect the process (Al Mogren, 2016).

Urban growth boundaries are not substitutes for comprehensive plans, but they do provide a basis for the provision of infrastructure, utilities and services. Another most important contributions of the UGB is institutionalizing the concept of infrastructure provision by the private sector, something that was not intended at the time of its initiation.

Three other ADA initiatives have been extremely important to the overall design of the city. One was the Ministry of Foreign Affairs (1984) by Henning Larsen and its staff housing (1983) by Speerplan Regional Und Stadtplaner (GMBH and CRS with the involvement of Ali Shuaibi as ADA adviser). This successful housing project, employing dwelling clusters around cul-de-sacs with exterior access and an auto-free recreational spine, has now been emulated in the al-Hamra neighbourhood (1994) of Riyadh, in Medina, and elsewhere in Saudi Arabia (Al-Hathloul, 2003). The Second has been ADA's rebuilding of Qasr-al-Hukm, the Justice Palace District, including the entire old walled city and an additional area to its west. The first redevelopment plan here was by Franco Albini (1978); the second was by Beeah (1983), subsequently revised by ADA staff (Al-Angari, 1997). The third is the redevelopment of al-Murabba', known as the King Abdulaziz Historic Center (1998). The urban design for this project was by Beeah and Rasem Badrn, and it has subsequently involved the renovation or new construction of a series of buildings designed by several architects (Al-Hathloul, 2003). This project represents a return to the city's roots. Located on the old Murabba' site, its completion marks the centennial of the beginning of the process that led to Saudi Arabia's unification. Its high-quality urban spaces, magnificent architecture, and well-thought-out linkages of traditional and modern forms create a complementary focal point to Qasr Al-Hukm in the center of the city, and the Diplomatic Quarter in the northwest.

\section{Stage 6, The Metropolitan Development Strategy for Arriyadh (MEDSTAR)}

The most important initiative undertaken by ADA is the MEDSTAR project (Metropolitan Development Strategy for Arriyadh). By the late 1990's Riyadh was a very fast growing city with a population of more than 4 million and an 
annual growth rate of $8 \%$. Forecasts, then indicated that the total population of Riyadh will reach 10 million by 2020. This necessitated the preparation of a comprehensive strategic plan to accommodate this growth and address the city requirements and functions. Accordingly, in 1996, the ADA assigned Dar ar-Riyadh and Parsons to prepare a strategic vision and a plan for Riyadh aiming at driving and guiding the future development in the city, to prepare strategic alternatives for the comprehensive city development, and an implementation plan for this strategy. The study covers the whole metropolitan area of about $4900 \mathrm{~km}^{2}$. With the development of the project the ADA staff got more involved and the work was performed jointly in house by the consultant and the ADA staff (HCDR, 1997; Garba, 2004).

The study resulted in a future vision for Riyadh for the next fifty years; an urban development strategy which consists of: sectoral policies, the Metropolitan structure plan, and an urban Management plan setting up the organizational structure for the city; and implementation instruments and programs as well. The most important and far reaching innovation of the MEDSTAR is the restructuring of the city. The plan proposes a gradual spatial change of the organization of the city into a multi-center system which locates new concentration in the new development areas, while keeping all major services and employment in the central area and the central spine (Figure 11). This calls for establishing:

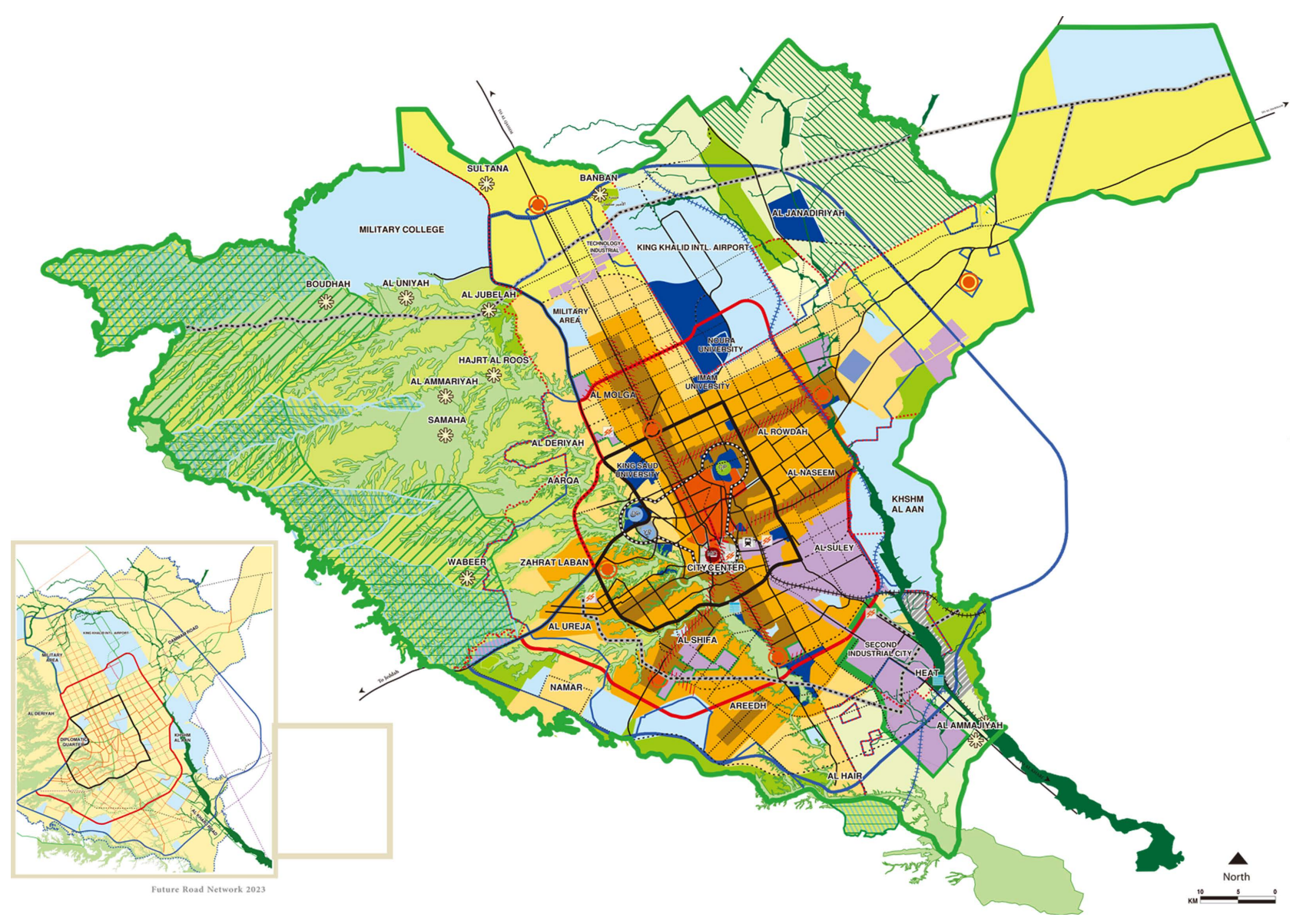

Figure 11. Riyadh-MEDSTAR structure plan 2030. Source: ADA, 2013: p. 4. 
1) five new metropolitan sub-centers with higher order services to serve people in the outward growing residential developments, located $15-20 \mathrm{~km}$ away from the city centers each in different directions.

2) Activity spines to link the metropolitan subcenters with the historical city.

3) The historical city as a center of such unique services as the central mosque, the seat of the governor, the metropolitan Municipality, the high court and headquarters of banks and international companies.

4) The central area, defined by the historic city, the area of the Royal court and Diplomatic quarter and the future central park at the old airport. These nodes are to provide the base for an imposing image of the capital.

5) New suburban cities each will cater for 1 million inhabitants.

6) An effective public transportation system as the backbone of the structure plan with major transport corridors defined and relevant technologies proposed (HCDR, 2003).

The MEDSTAR study has been approved by the High Commission for the Development of Arriyadh in 2001 and its propositions have been continuously developed and updated since then (ADA, 2015a, 2015b, 2013; HCDR, 2003).

Three of the stated proposed actions have a major impact on Riyadh physical development. These are the subcenters, the new suburban cities and the public transportation system. According to MEDSTAR, the subcenters will encompass public and private sector functions, i.e. economic activities, offices, companies and banks, shopping malls, administrative, socio-cultural and recreational activities. They will act to support city center by providing activities and services in areas that are too far from the city center. They will also create jobs and commercial activities in different parts of the city, thus reducing trips to the city center, and will act to decentralize the city urban management (ADA, 2015b). One of these subcenters, King Abdullah Financial Center, in line with the original central spine to the north is reaching completion. The Other four subcenters, to the south, east, west and southwest of the city center, are awaiting initiation by private developers. The plan calls for extending the city spine towards these sub centers on the east, south and west.

As to the proposed northern and eastern suburbs, they seem to have come out as a de facto. During the late 1990's and the beginning of the 21st century, Riyadh Municipality has been pressured to provide subdivided land for government grants. Thus the municipality undertook the subdivision of an area $60 \mathrm{~km}$ to the east of the city center and another area $30 \mathrm{~km}$ north of the city center, without any provision of infrastructure, utilities or services. Although MEDSTAR states clearly that the ideal planning solution would be a city with a continuous physical development, rather than developing separate suburbs around Riyadh, planners have to confront an existing condition. Thus the two suburbs were proposed with a strong recommendation to follow a controlled growth model in their development, and connect them in the future to the city center through the metro (ADA, 2015a).

The third proposed action that will have a major impact on Riyadh physical 
development is the implementation of a public transportation system. Doxiadis plan has emphasized the private automobile as the only mode of transportation for the city. Thus Riyadh has never had a full public Transportation. Based on MEDSTAR proposal a royal order was issued on April 24th, 2012 to allocate the needed budget for the design and implementation of a public transportation network for the city of Riyadh. The aim is to have a reliable, efficient and affordable transport. This is to be achieved through an accessible and integrated multi-modal network. The network know as Riyadh Public Transport Network (RPTN) is composed of Metro lines with Bus Rapid Transit (BRT), community bus lines, feeder buses and park and ride facilities at the city's gates (Figure 12). The project is already underway and expected to be operating by the end of 2018 (ADA, 2016).

As a result of the implementation of the RPTN project ADA is currently undertaking a preliminary study of Transit Oriented Development (TOD) within the city of Riyadh. The outcome will represent a TOD Strategy for Riyadh future development. This study calls for intensifying mixed use activities and increase densities around the stations (Figure 13). It states that: "The coverage of the transit system provides the opportunity for a range of stakeholders to become involved in various elements and scales of TOD within the city, from large high end developments in the CBD to neighborhood level mixed-use development which will enhance existing communities" (HCDR, 2016: p. 7). The study also calls for measures to be developed and put in place to encourage TOD style of development and to begin a shift in the focus from low density single use development in outlying areas of the city to higher density, mixed use and transit focused centers (HCDR, 2016).

The impact of RPTN and the TOD strategy coupled with the subcenters concept will lead to a complete restructuring of the city order (Figure 14). Emphasis on the central spine will no longer persist. The spine width is being expanded towards King Abdukaziz road two km. east, parallel to the spine. King Abdullah road and Almadinah road, both running east-west leading to proposed eastern and western subcenters, are being emphasized as extensions of the spine to connect with the proposed subcenters. With the completion and operation of RPTN and the implementation of the TOD Strategy a new Riyadh will shape out in the years to come.

\section{Concluding Remarks}

Riyadh had grown from a small town into a large metropolis during the past fifty years. The speed and scale of its transformation have had few parallels. In the late 1960's, Doxiadis was commissioned to develop the city's first Master plan. Doxiadis had always predicted that cities would grow much larger, anticipating that the world urban population would grow from 33\% in 1960 to over $97 \%$ in 2100 (Bromley, 2002). Thus he developed and applied the concept of Dynapolis in his work. In Riyadh this concept with its spine the modulus of $2 \times 2 \mathrm{~km} \mathrm{su}-$ perblock and the supergrid has produced a functional, dynamic and growing 


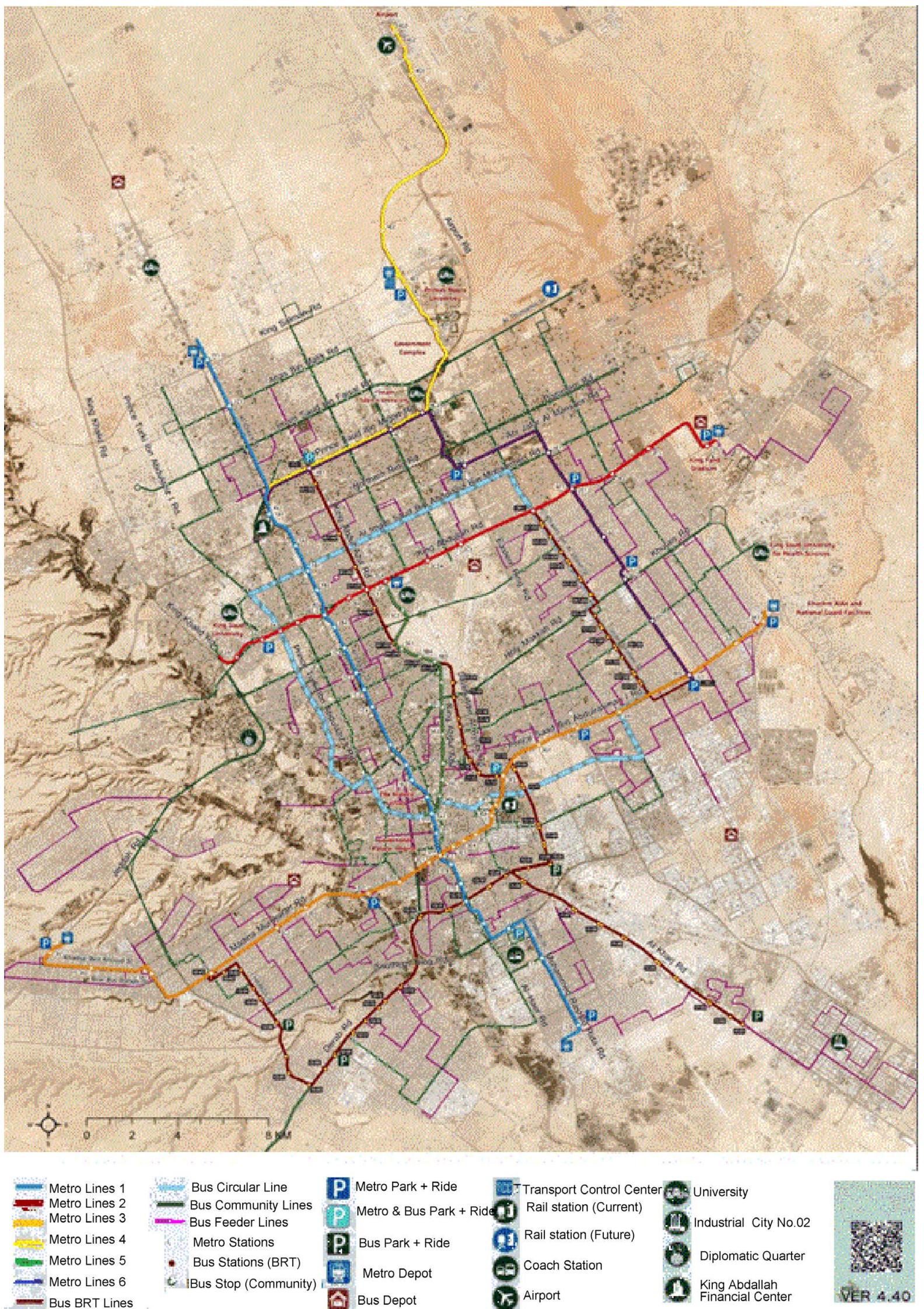

Figure 12. Plan of RPTN project. Source: ADA, 2016: p. 6. 


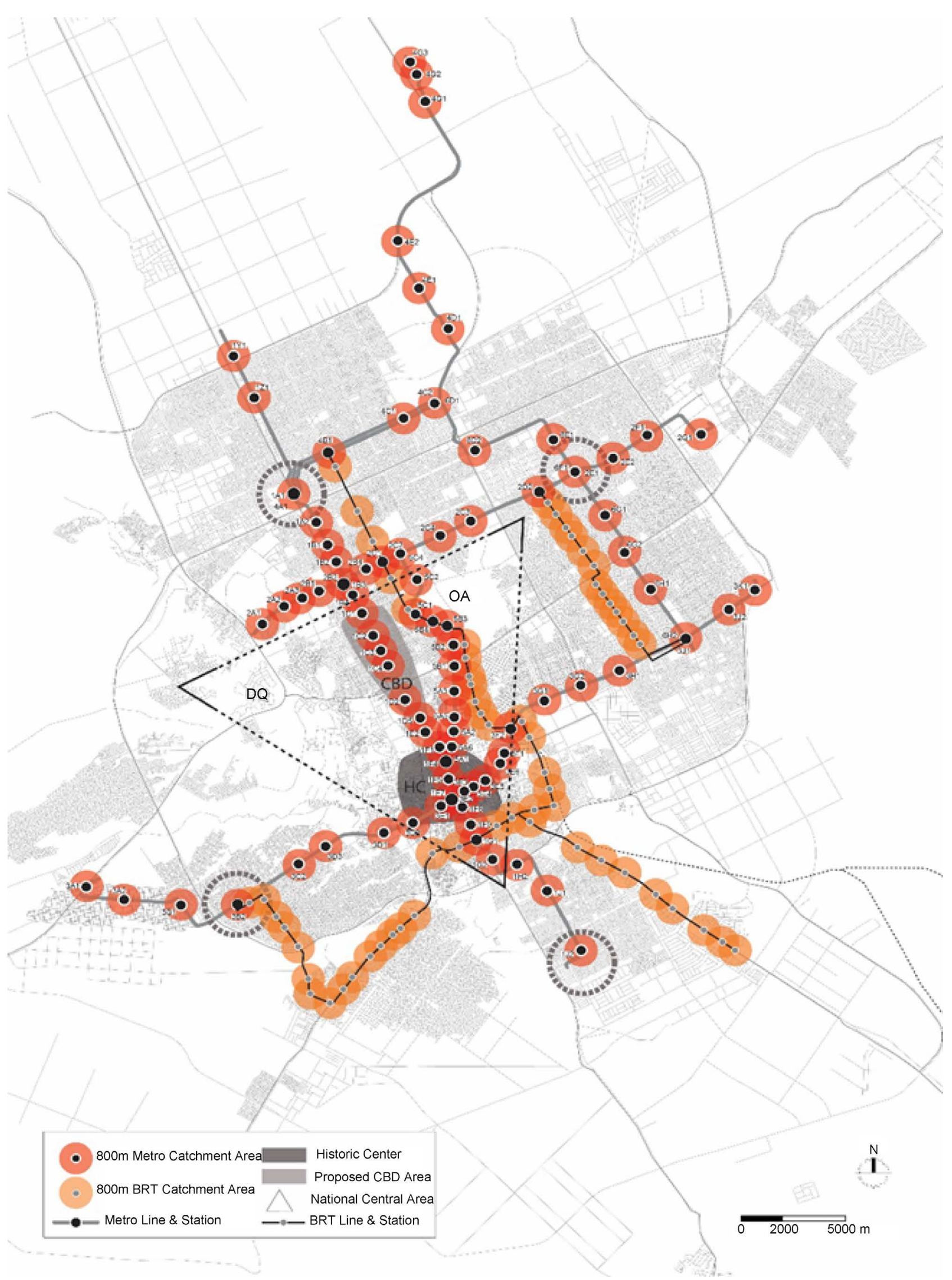

Figure 13. TOD—metro stations' catchment area. Source: HCDR, 2016: p. 6. 


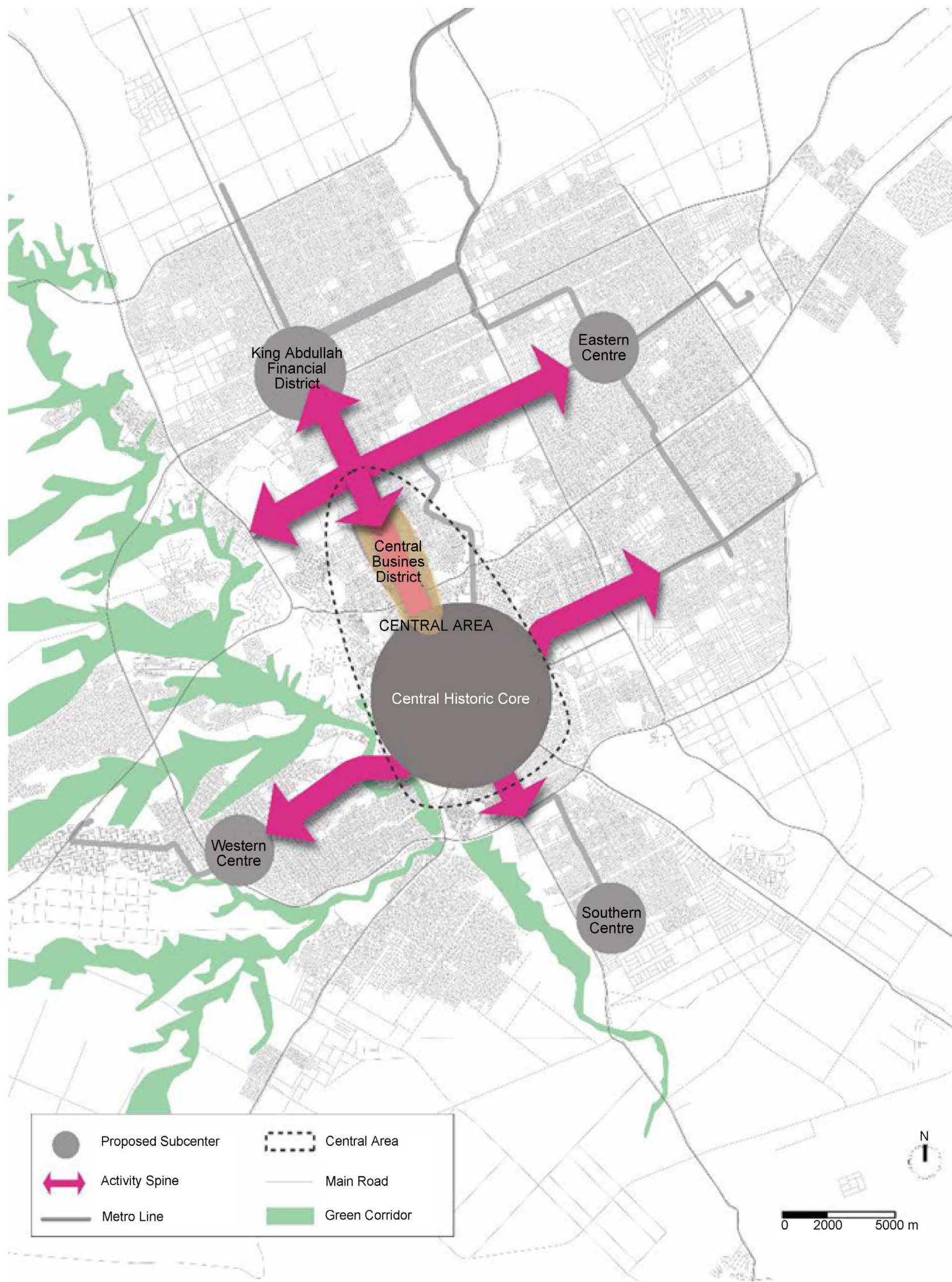

Figure 14. Riyadh metropolitan TOD strategy-subcenters. Source: HCDR, 2016: p. 9. 
city, which have continuously adapted to changing circumstances and changing agendas. The superblock (modulus) of $2 \times 2 \mathrm{~km}$ with the supergrid represented a growth model that allowed its repetition and multiplication by planners later on beyond the plan original boundaries. It provided a larger framework which allowed for adaptability and change through time. The city was structured to expand as a rational logical system. Urban infrastructure and land subdivisions would occur through a process of measured extension based on the aggregation of the modulus unit. The plan emphasis on high-speed movement channels for transportation and for the provision of infrastructure services has enabled the rapid deployment of new territories for subdivisions and development.

The SCET plan and MEDSTAR had both followed the approach, method and instruments developed by Doxiadis plan but at a much larger scale. However, MEDSTAR introduces three new propositions: to create five sub centers $10-15$ $\mathrm{km}$ from the city center and expand the city spine towards these subcenters; develop two suburbs north and east of the existing city, and the ongoing Riyadh Public Transport Network project (RPTN). These propositions represent a major departure from the original Doxiadis plan. The central spine in its liner form and concentrated development activities will no longer persist. This spine will be expended into branching spines towards the subcenters with their high density development. The future shift towards the Transit Oriented Development around the metro stations will contribute more to the weakening of the original spine. The impact of these planning proposals, particularly the subcenters, RPTN and the Transit Oriented Development strategy will change the urban order and structure of the city.

\section{References}

Al-Alsheikh, M., Al-Alsheikh, A., AlFayadh, \& El-Seri, A. (1990). The Diplomatic Quarter in Riyadh. In Proceedings of the Symposium on Urban Regeneration and the Shaping of Growth, The Aga Khan Program for Islamic Architecture at Harvard and MIT (pp. 79-85).

Al-Angari, \& Mohammed, A. B. (1997). The Revival of the Architectural Identity: The City of Arriyadh. PhD Dissertation, Edinburgh: University of Edinburgh.

Al-Hathloul, S. (1996). The Arab-Muslim City: Tradition, Continuity and Change in the Physical Environment. Riyadh: Dar Al-Sahan.

Al-Hathloul, S. (2003). Riyadh, Saudi Arabia. In R. S. Sennott (Ed.), Encyclopedia of 20th-Century Architecture (pp. 1113-1115). Chicago: Fitzroy Dearborn Publishers.

Al-Hathloul, S., \& Mughol, M. A. (2004). Urban Growth Management, the Saudi Experience. Habitat International, 28, 609-623.

Al-Hathloul, S., Al-Hussayen, M., \& Shuaibi, A. (1975). Urban Land Utilization, Riyadh, Saudi Arabia. Cambridge, MA: Education/Research Program, USD, MIT.

Al Mogren, F. A. B. A. (2016). Turning Points: City-Building in Riyadh and the Gulf. Master Thesis, Cambridge, MA: Harvard University.

Arriyadh Development Authority (ADA) (2013). Riyadh Metropolitan Development Strategy, Executive Summary, 2013 Update. (In Arabic)

Arriyadh Development Authority (ADA) (2015a). Updated Master Plans for Northern and Eastern Suburbs, Riyadh. (In Arabia) 
Arriyadh Development Authority (ADA) (2015b). Riyadh Sub Centers Report. (In Arabic)

Arriyadh Development Authority (ADA) (2016). Background of the Riyadh Public Transport Network.

Bromley, R. (2002). Doxiadis and the Ideal Dynapolis: The Limitations of Planned Axial Urban Growth. Ekistics, 69, 317-330.

Deputy Ministry for Town Planning (DMTP) (1989). Saudi Cities Atlas; Urban Boundaries. Riyadh: MOMRA. (In Arabic)

Doxiadis (1968-1972). Riyadh Master Plan, Report No. A-1 to A-35.

Doxiadis (1968). Existing Conditions, No. A-1.

Doxiadis (1971). Riyadh Master Plan, No. A-19.

Facey, W. (1992). Riyadh: The Old City. London: Immel.

Garba, S. B. (2004). Managing Urban Growth and Development in the Riyadh Metropolitan Area, Saudi Arabia. Habitat International, 28, 593-608.

General Authority for Statistics (GAfS). Census Data for the Years 1992, 2004, 2010. Riyadh, KSA.

High Commission for the Development of Arriyadh (HCDR) (2016). Transit Oriented Development, Strategy \& Case Studies for Riyadh.

High Commission for the Development of Riyadh (HCDR) (1997). Metropolitan Development Strategy for Arriyadh (MEDSTAR) (Vol. 1-20).

High Commission for the Development of Riyadh (HCDR) (2003). Summary Report, MEDSTAR, Final Reports (Vol. 12-13).

High Committee for the Evaluation of the Riyadh Master Plan (1973). Taqrir al-Lajnah al-Uliya li-Taqyim al-Mukhatat al-Âmm li-Madinat al-Riyadh.

Hsiang, J. (2010). The Doxiadis Effect. In S. Archis (Ed.), AlManakh 2 (p. 248). Amesterdam: Stichting Archis.

Khan, A. Z. (2010). Rethinking Doxiadis’ Ekistical Urbanism. Positions, 1, 6-39.

Middleton, D. A. (2009). Growth and Expansion in Post-War Design Strategies: C.A. Doxiadis and the First Strategic Plan for Riyadh Saudi Arabia (1968-1972). PhD Thesis, Atlanta, GA: Georgia Institute of Technology.

Othman, Z. (1995). The Role of Planning Authorities in Urban Development: A Case of Arriyadh Development Authority. In S. Al-Hathloul, \& N. Edadan (Eds.), Urban Development in Saudi Arabia (pp. 307-329). Riyadh: Dar al-Sahan.

Philby, J. B. (1959). Riyadh; Ancient and Modern. Middle East Journal, 13, 129-142.

SCET International/SEDES (1982). Riyadh Revised Master Plan. T.R. No. 8, MOMRA.

SCET International/SEDES (1979). Riyadh Action Master Plan. T.R. 1-10, MOMRA. 
Submit or recommend next manuscript to SCIRP and we will provide best service for you:

Accepting pre-submission inquiries through Email, Facebook, LinkedIn, Twitter, etc. A wide selection of journals (inclusive of 9 subjects, more than 200 journals)

Providing 24-hour high-quality service

User-friendly online submission system

Fair and swift peer-review system

Efficient typesetting and proofreading procedure

Display of the result of downloads and visits, as well as the number of cited articles Maximum dissemination of your research work

Submit your manuscript at: http://papersubmission.scirp.org/

Or contact cus@scirp.org 